\title{
STRATEGI BADAN PENGAWAS PEMILU KABUPATEN SERANG DALAM PENCEGAHAN PRAKTIK POLITIK UANG
}

\author{
M. Asmawi ${ }^{1}$, Amiludin'2 ${ }^{2}$ dan Edi Sofwan ${ }^{3}$ \\ 1awihaber@gmail.com,2tsamanytrans@gmail.com dan3edisofwan85@gmail.com \\ 1 Universitas Banten Jaya, \\ 2 Universitas Muhammadiyah Tangerang \\ 3 Universitas Pamulang \\ Correspondence Email: awihaber@gmail.com
}

\begin{abstract}
The process of regional head election cannot be carried out with the wishes of the parties and at will, as a country that upholds the values of democracy and as a rule of law which is reformulated in article 1 paragraph 3 of the 1945 Constitution that the implementation of elections to the regions must be based on the value of justice. strategies in preventing illegal acts committed by election contestants to the regions, especially money politics against the community, the attacking regency election supervisory body needs to carry out socialization methods to the community and also political parties, as well as conduct anti-money politics patrols during the calm period which often occurs by the team. success. The research method that I use in writing this article is to use empirical normative legal research methods. The primary data source is the result of interviews with several members of the Bawaslu of Serang Regency. The data analysis in writing this article is a qualitative way. This is because in analyzing an object of research, this method is used to explain the data used.
\end{abstract}

KEYWORDS: Election for Regional Heads, Election Supervisory Agency, Strategy, Money Politics

\section{PENDAHULUAN}

Penjelasan kembali mengenai negara hukum atau biasa disebut "rechtsstaat" kembali dirumuskan pada pasal 1 ayat 3 yang mana sebelumnya hanya tercantum pada penjelasan UUD 1945.(Siallagan, 2016) Sebagai negara hukum Indonesia harus menjadikan hukum sebagai panglima kehidupan bernegara, bukan untuk politik maupun untuk kepentingan ekonomi.(Airlangga, 2019; Aswandi \& Roisah, 2019) Karena itu, jargon yang biasa digunakan dalam bahasa Inggris untuk menyebut prinsip Negara Hukum adalah 'the rule of law, not of man'. (Tamanaha, 2012) Yang disebut pemerintahan pada pokoknya adalah hukum sebagai sistem, bukan orang per orang yang hanya bertindak sebagai 'wayang' dari skenario sistem yang mengaturnya.(Asshiddiqie, 2011) 
Ide pembentukan negara hukum dibangun dengan cara mengembangkan perangkat hukum dan sistem yang fungsional dan berkeadilan.(Anshar, 2019; Azis, 2018) Selain itu juga negara hukum dikembangkan dengan menata suprastruktur dan infrastruktur kelembagaan politik, ekonomi dan social yang tertib dan teratur, serta dibina dengan membangun budaya dan kesadaran hukum yang rasional dan impersonal dalam kehidupan bermasyarakat, berbangsa dan bernegara.(Mu'as, 2015) Oleh karena itu perlu dibangun sebuah sistem hukum dan perlu juga dibangun penegakan hukum sebagaimana mestinya, dengan diawali konstitusi sebagai hukum dasar dan berkedudukan tinggi. (Azis, 2018)

Negara demokrasi mengutamakan kepentingan umum dari pada pribadi, artinya demokrasi merupakan bentuk pemerintahan dimana formulasi kebijakan, secara langsung atau tidak ditentukan oleh suara mayoritas warga yang memiliki hak suara melalui wadah pemilihan. Demokrasi bicara soal kehendak rakyat, demokrasi juga bisa sebagai kebaikan bersama, jadi pemerintahan demokratis adalah menciptakan kebaikan bersama yang ditetapkan melalui kontrak politik, bicara demokrasi berarti berhubungan dengan pemilihan umum.(Bachtiar, 2014; Gaffar, 2013) Mengingat sistem demokrasi merupakan perintah langsung dan amanat dalam UUD 1945, dan melalui perwujudan kedaulatan rakyat dalam sistem pemerintahan diyakini hal tersebut dapat terealisasi secara komprehensif dengan adanya pelaksanaan pemilihan umum kepala daerah secara langsung dan juga serentak.(Hofi, 2018; Pratiwi, 2017)

Pelaksanaan pemilihan kepala daerah tidak bisa dilaksanakan dengan semaunya tanpa adanya hukum yang mengatur, Demokrasi harus berjalan sesuai dengan prosedur hukum, selain itu pemilihan kepala daerah merupakan kebutuhan yang sangat penting dalam peradaban demokrasi sekaligus mekanisme pemilihan ditentukan oleh masyarakat yang dilibatkan langsung dalam pengisian jabatan yang diatur melalui peraturan Perundang-undangan.(Manar, 2018)

Penyelenggaraan pemilu dan pilkada tidak terlepas dari asas yang harus dijalankan dengan baik, yakni asas langsung, umum, bebas, rahasia, jujur dan adil.(Susilo \& H Soehino, 2006; Wardhani, 2018) Penulis berpikir kelima asas tersebut memiliki kedudukan yang sama dalam menghasilkan pejabat yang berintegritas tinggi, berdasarkan data dari Indonesian Corruption Watch (ICW) 
menilai ada 10 permasalahan yang kerap terjadi dalam pelaksanaan pilkada, Adapun 10 potensi permasalahan yang membayangi gelaran pilkada serentak diantaraya adalah:

1. Jual beli pencalonan (candidat buying) antara kandidat dan partai politik.

2. Munculnya nama bermasalah (mantan narapidana atau tersangka korupsi) dan calon dengan dinasti.

3. Munculnya calon tunggal.

4. Kampanye berbiaya tinggi akibat dinaikannya batasan sumbangan dana kampanye dan diizinkannya calon memberikan barang seharga maksimal Rp 25 ribu kepada pemilih.

5. Pengumpulan model ilegal (jual beli izin usaha, jual beli jabatan, suap proyek) dan politisasi program pemerintah (dana hibah, bantuan sosial, dana desa dan anggaran rawan lainnya) untuk kampanye.

6. Politisasi birokrasi dan pejabat negara, mulai dari birokrat, guru hingga institusi TNI/Polri.

7. Politik uang (jual beli suara pemilih).

8. Manipulasi laporan dana kampanye.

9. Suap kepada Penyelenggara Pemilu.

10. Korupsi untuk pengumpulan modal, jual beli perizinan, jual beli jabatan, hingga korupsi anggaran.

Sebagai Lembaga negara, badan pengawas pemilu dibentuk berdasarkan adanya krisis kepercayaan masyarakat dalam pelaksanaan pemilu yang pada awal mulanya krisis kepercayaan inilah yang mulai dikooptasi kekuatan rezim penguasa sejak 1971.(Ridho, 2018) Mulai muncul protes-protes dari masyarakat karena diduga banyaknya manipulasi yang dilakukan oleh petugas pemilu saat itu dan kemudian menjadi cikal bakal urgensi kehadiran Bawaslu.(Abhan, 2018; Surbakti \& Fitrianto, 2015) Kehadiran Bawaslu dalam desain Undang-Undang Nomor 7 Tahun 2017 tentang Pemilihan Umum, di antaranya ditugaskan untuk mencegah politik uang dan mendorong pengawasan partisipatif.(Nabila Amrie, 2020) Tantangan mandat ini yang kemudian mendorong Bawaslu untuk melakukan terobosan mencegah sekaligus melawan politik uang dengan model membangun gerakan 
sosial berbasiskan desa/kelurahan yang dinamakan Desa Anti Politik Uang (Desantiku) di setiap Kabupaten/Kota. Gerakan ini mengasumsikan akan melibatkan makin banyak elemen desa dalam pengawasan partisipatif, seperti halnya gerakan anti politik uang yang dilakukan oleh Bawaslu Kabupaten Serang.(Nabila Amrie, 2020)

Tahun 2020 data yang penulis dapatkan melalui keterangan bawaslu bahwa kasus pilkada yang sedang ditangani sebanyak 104 kasus dugaan politik uang pada pelaksaan pilkada dan hal ini secara tidak langsung butuh peran dari bawaslu sendiri dalam hal strategi menghilangkan politik uang agar terciptanya pemilihan yang berdaulat sekaligus mendapatkan kepercayaan dari masyarakat.(ManikFahriza et al., 2019; Nurlita, 2020)

Pada penulisan artikel ini penulis akan lebih menitikberatkan kepada permasalahan politik uang yang dari pelaksanaan pemilu pertama kali tahun 1955 sampai dengan sekarang pelanggaran terhadap politik uang selalu terjadi dan hal ini akan membunuh rasa demokrasi dan juga menghilangkan asas pemilihan umum yakni asas langsung, umum, bebas, rahasia, jujur dan adil. Dan permasalahan yang akan dijadikan pembahasan pada artikel ini adalah bagaimana strategi badan pengawas pemilu kabupaten serang dalam pencegahan praktik politik uang dan hambatan apa saja yang didapatkan terhadap pelaksanaan strategi tersebut

\section{METODE PENELITIAN}

Mekmanisme penulisan artikel ini menggunakan metode Penelitian hukum normatif empiris, yang dalam hal ini penulis akan menjelaskan bahwa "Pada penelitian hukum jenis ini, seringkali hukum dikonsepkan sebagai apa yang tertulis dalam peraturan perundang-undangan dan hasil wawancara berdasarkan data empiris.(Jonaedi Efendi et al., 2018; Qamar et al., 2017) Adapun sumber data primer ini adalah hasil wawancara dengan beberapa anggota Bawaslu Kabupaten Serang. Adapun Analisa data pada penulisan artikel ini adalah dengan cara kualitatif, Hal ini dikarenakan dalam menganalisis suatu objek penelitian, metode ini digunakan terhadap penjelasan data yang digunakan. Adapun data yang dimaksud yakni dalam hal penjelesan terhadap data hasil wawancara, peraturan hukum yang berkaitan 
dengan permasalahan penelitian, data studi kepustakaan yakni literature yang yang berkaitan dengan permasalahan penelitian.(Jogiyanto Hartono, 2018; Nugrahani \& Hum, 2014)

\section{HASIL DAN ANALISA}

Sistem demokrasi hadir sebagai salah satu cara yang paling tepat walaupun tidak paling sempurna dalam hal mengatur tata kehidupan manusia dalam bernegara, dan berdasarkan sejarah yang ada demokrasi hadir sebagai alat untuk memanusiakan manusia. Badan Pengawas Pemilu (Bawaslu) sebagai lembaga penyelenggara pemilu yang bertugas melakukan pengawasan terhadap penyelenggaraan pemilu memiliki wewenang antara lain mengawasi pelaksanaan tahapan-tahapan pemilu, menerima laporan-laporan dugaan pelanggaran pemilu, dan menindaklanjuti temuan atau laporan kepada instansi yang berwenang.

Tugas, Wewenang, dan Kewajiban Pengawas Pemilu berdasarkan amanat Undang-Undang Nomor 7 Tahun 2017 tentang Pemilihan Umum adalah sebagai berikut :

1. Menyusun standar tata laksana pengawasan Penyelenggaraan Pemilu untuk pengawas Pemilu di setiap tingkatan.

2. Melakukan pencegahan dan penindakan terhadap:
a. Pelanggaran Pemilu
b. Sengketa proses Pemilu

3. Mengawasi persiapan Penyelenggaraan Pemilu, yang terdiri atas:
a. Perencanaan dan penetapan jadwal tahapan Pemilu
b. Perencanaan pengadaan logistik oleh KPU
c. Sosialisasi Penyelenggaraan Pemilu; dan
d. Pelaksanaan persiapan lainnya dalam Penyelenggaraan Pemilu sesuai dengan ketentuan peraturan perundang-undangan.

4. Mengawasi pelaksanaan tahapan Penyelenggaraan Pemilu, yang terdiri atas:
a. Pemutakhiran data pemilih dan penetapan daftar pemilih sementara serta daftar pemilih tetap;
b. Penataan dan penetapan daerah pemilihan DPRD kabupaten/kota; 
c. Penetapan Peserta Pemilu;

d. Pencalonan sampai dengan penetapan Pasangan Calon, calon anggota DPR, calon anggota DPD, dan calon anggota DPRD sesuai dengan ketentuan peraturan perundang-undangan;

e. Pelaksanaan dan dana kampanye;

f. Pengadaan logistik Pemilu dan pendistribusiannya;

g. Pelaksanaan pemungutan suara dan penghitungan suara hasil Pemilu di TPS

h. Pergerakan surat suara, berita acara penghitungan suara, dan sertifikat hasil penghitungan suara dari tingkat TPS sampai ke PPK

i. Rekapitulasi hasil penghitungan perolehan suara di PPK, KPU Kabupaten/Kota, KPU Provinsi, dan KPU

j. Pelaksanaan penghitungan dan pemungutan suara ulang, Pemilu lanjutan, dan Pemilu susulan; dan

k. Penetapan hasil Pemilu;

5. Mencegah terjadinya praktik politik uang

6. Mengawasi netralitas aparatur sipil negara, netralitas anggota Tentara Nasional Indonesia, dan netralitas anggota Kepolisian Republik Indonesia

7. Mengawasi pelaksanaan putusan/keputusan, yang terdiri atas:

a. Putusan DKPP

b. Putusan pengadilan mengenai pelanggaran dan sengketa Pemilu;

c. Putusan/keputusan Bawaslu, Bawaslu Provinsi, dan Bawaslu Kabupaten/ Kota

d. Keputusan KPU, KPU Provinsi, dan KPU Kabupaten/Kota dan

e. Keputusan pejabat yang berwenang atas pelanggaran netralitas aparatur sipil negara, netralitas anggota Tentara Nasional Indonesia, dan netralitas anggota Kepolisian Republik Indonesia

8. Menyampaikan dugaan tindak pidana Pemilu kepada Gakkumdu;

9. Mengelola, memelihara, dan merawat arsip serta melaksanakan penyusutannya berdasarkan jadwal retensi arsip sesuai dengan ketentuan peraturan perundangundangan; 
10. Mengevaluasi pengawasan Pemilu;

11. Mengawasi pelaksanaan Peraturan KPU; dan

12. Melaksanakan tugas lain sesuai dengan ketentuan peraturan perundangundangan.

Selain tugas, bawaslu juga mempunyai wewenang seperti menerima dan menindaklanjuti laporan yang berkaitan dengan dugaan adanya pelanggaran terhadap pelaksanaan peraturan perundang-undangan yang mengahrr mengenai Pemilu, Memeriksa, mengkaji, dan memutus pelanggaran, administrasi Pemilu, Memeriksa, mengkaji, dan memutuss pelanggaran politik uang dan Merekomendasikan kepada instansi yang bersangkutan mengenai hasil pengawasan terhadap netralitas aparatur sipil-negara, netralitas anggota Tentara Nasional Indonesia, dan netralitas anggota Kepolisian Republik Indonesia.

Pemilihan Umum Kepala Daerah adalah sarana dan pelaksanaan kedaulatan rakyat di wilayah provinsi dan/atau kabupaten/kota berdasarkan Pancasila dan Undang-Undang Dasar Negara Republik Indonesia Tahun 1945 untuk memilih Kepala Daerah dan Wakil Kepala Daerah secara demokrasi. Pemilihan Kepala Daerah atau yang sering disebut Pilkada dalam penyelenggaraannya di Indonesia merupakan sebuah polemik di masyarakat yang sampai saat ini belum terselesaikan. Di Indonesia dikenal dua sistem penyelenggaraan Pemilihan Kepala Daerah (Pilkada), yaitu pilkada secara tidak langsung yang dilakukan pada masa awal kemerdekaan serta pilkada secara langsung sesudah era reformasi. Pemilihan Kepala Daerah langsung diatur dalam Undang-Undang Nomor 10 Tahun 2016 tentang perubahan kedua atas Undang-Undang Nomor 1 Tahun 2015 tentang Penetapan Peraturan Pemerintah Pengganti Undang- Undang Nomor 1 Tahun 2014 tentang Pemilihan Gubernur, Bupati, dan/atau Walikota menjadi Undang-Undang.

Munculnya pemilihan kepala daerah secara langsung dimulai dengan berlakunya Undang-Undang Nomor 32 Tahun 2004 tentang Pemerintahan Daerah yang merupakan Undang-Undang hasil revisi atas Undang-Undang Nomor 22 Tahun 1999 telah menciptakan suasana baru dalam proses 
Pemilihan Kepala Daerah (Pilkada), baik di tingkat provinsi maupun di tingkat kabupaten/kota. Apabila sebelumnya Gubernur, Bupati dan/atau Walikota dipilih oleh sekelompok orang tertentu, yakni para anggota Dewan Perwakilan Rakyat Daerah (DPRD) sesuai dengan tingkatannya masing-masing, maka dengan berlakunya Undang-Undang tersebut mereka harus dipilih secara langsung oleh seluruh rakyat yang memiliki hak pilih di masing-masing daerah. Karena cara pemilihan Kepala Daerah tidak lagi melalui lembaga perwakilan, melainkan langsung oleh rakyat.

Pemilihan kepala daerah bukan hanya memilih penguasa daerah, tetapi lebih merupakan mencari pemimpin yang mampu melayani dan mengabdi untuk kepentingan seluruh masyarakat. Pola pikir lama yang menempatkan kepala daerah sebagai penguasa yang harus dilayani harus diubah secara radikal menjadi pemimpin yang sesungguhnya, bertugas memberikan pelayanan kepada masyarakat. Dalam konteks ini sesungguhnya tugas kepala daerah terpilih sangat berat dan hanya mereka yang mampu mengemban tugas tersebut. Oleh karena itu, semua energi daerah harus dicurahkan untuk memilih pemimpin yang terbaik bagi kemajuan dan kesejahteraan daerah selama proses pemilihan kepala daerah berlangsung.

Akan tetapi sampai saat ini, Indonesia negara yang dianggap paling demokratis dalam hal apapun terutama dalam hal pemilihan ternyata masih saja menggunakan politik uang dalam hal memenangkan pertarungan dalam perhelatan pemilihan umum ataupun kepala daerah. Secara definisi Istilah politik uang ialah menggunakan uang untuk mempengaruhi keputusan tertentu, dalam hal ini uang dijadikan alat untuk mempengaruhi seseorang dalam menentukan keputusan. Dengan adanya politik uang ini, maka putusan yang dihasilkan tidaklah lagi berdasarkan idealistis mengenai baik tidaknya keputusan tersebut, melainkan semata-mata didasarkan oleh kehendak si pemberi uang, karena yang bersangkutan sudah merasa teruntungkan.

Dengan adanya politik uang secara tidak langsung kualitas seorang pemimpin menjadi tidak penting dan digantikan oleh kemampuan untuk "membeli" suara sebanyak mungkin terlepas apapun visi dan misi yang diusung. 
Selain menghilangkan kesempatan untuk memunculkan pemimpin yang berkualitas dalam setiap tingkatan, money politics juga menimbulkan berbagai gejolak yang mengganggu stabilitas nasional, seperti aksi anarki massa atau konflik horizontal yang berkepanjangan.

Mengutip pendapat pakar tata negara dalam hal ini yusril ihza mahendra menjelaskan bahwa money politic yaitu mempengaruhi massa pemilu dengan imbalan materi. Dalam hal ini, pelaksanaan demokrasi selalu dikotori dengan cara-cara yang tidak baik. Money politic kini tidak hanya terjadi ditingkat pemerintahan pusat tetapi sudah sampai di pelosok daerah yang jauh dari pusat pemerintahan. Kegiatan ini sudah tidak asing lagi, bahkan pelakunya tidak lagi sembunyi-sembunyi tetapi sudah berani terang-terangan. Baik lewat sumbangan sarana prasarana, perbaikan jalan, renovasi sarana sosial, sampai masing-masing individu menerima uang "panas", dengan syarat memberikan suaranya pada ajang pemilihan dan pemungutan suara.

Berdasarkan penjelasan diatas maka penulis akan berusaha memberikan sedikit pembahasan dan Analisa terkait strategi yang akan dilakukan oleh badan pengawas pemilu di kabupaten serang dalam hal pencegahan politik uang, Adapun strategi yagn dilakukan adalah dengan cara sebagai berikut:

\section{1) Sosialisasi kepada element masyarakat Pemilih dalam pencegahan politik uang pada pelaksanaan pemilihan kepala daerah}

Transaksi pemberian uang terkadang tidak dilakukan calon secara langsung tetapimelalui perantara tim sukses atau pihak-pihak yang berkepentingan dengan calon. Modusnya beragam seperti melalui acara pengajian, wiridan, PKK ibu-ibu di RT/RW di tingkat desa atau acara-acara sosial yang dikemas dengan kehadiran calon. Dalih yang paling umum untuk penyampaian pemberian uang atau barang adalah pengganti uang transportasi. Praktek pemberian uang dengan dalih pengganti transportasi jelas mengarah pada politik uang namun pembuktian hukumnya terkendala oleh konteks kejadian dan makna politik uang itu sendiri. Jika pemberian didalihkan sebagai ganti transportasi dan pada saat kejadian pembagian, sang calon tidak 
menyinggung visi, misi, dan tidak mengadakan ajakan untuk memilih dirinya, maka konteks pembagian transportasi sulit didakwakan sebagai politik uang.

Sesuai dengan amanat UU Nomor 7 Tahun 2017 tentang Pemilu yaitu Pasal 101 dijelaskan bahwa selain tugas mengawasi berjalannya proses pelaksanaan pemilu, Bawaslu Kabupaten juga bertugas untuk mencegah terjadinya praktik politik uang, berdasarkan keterangan dari Ketua Bawaslu Kabupaten Serang bahwa Bawaslu Kabupaten Serang melakukan upaya pencegahan dan juga penerapan strategi dengan cara sosialisasi kepada element masyarakat yang menjadi Pemilih dalam hal pencegahan tindak pidana politik uang yang diatur juga dalam undang-undang Nomor 10 Tahun 2016 tentang Pemilihan kepala daerah.

\section{2) Sosialisasi Terhadap Partai Politik Sebagai Pengusung Pasangan Calon Kepala Daerah}

Dalam rangka kelancaran kerja-kerja pengawasan, pencegahan, dam penindakan terhadap pelanggaran Pilkada dan penyelesaian sengketa proses Pilkada serentak tahun 2020, Bawaslu Kabupaten Serang membuat pemetaan permasalahan kepemiluan dengan menitik beratkan pada sejumlah sasaran, yaitu antara lain pemetaan terhadap potensi adanya politik uang yang akan dilakukan oleh setiap tim sukses. Selain itu untuk mencegah terjadinya pelanggaran politik uang yang dilakukan oleh para pihak yang bertarung di pilkada Serentak Kabuapten Serang Bawaslu Kabupaten Serang melakukan sosialisasi dan membangun komitmen dengan partai politik sebagai pengusung pasangan calon kepala daerah agar tidak melakukan praktik politik uang yang nantinya akan menciderai proses demokrasi.

\section{3) Patroli Anti Politik Uang Sebelum 3 Hari Menjelang Pelaksanaan Pilkada (Masa Tenang)}

Berdasarkan surat edaran nomor 0822 K.Bawaslu/PM.00.00/12/2020 Tentang Pelaksanaan Kegiatan Patroli Pengawasan Antipolitik Uang Pada Masa Tenang dalam pemilihan Gubernur dan Wakil Gubernur, Bupati dan Wakil Bupati, Walikota dan Wakil Walikota Tahun 2020. Sesuai dengan edaran ini bahwa dalam rangka optimalisasi pelaksanaan pengawasan tahapan 
khususnya dalam masa tenang pada pemilihan Gubernur dan Wakil Gubernur, Bupati dan Wakil Bupati, Walikota dan Wakil Walikota serentak lanjutan tahun 2020, bahwa Bawaslu disetiap provinsi, kabupaten, kota agar melaksanakan kegiatan "Patroli Pengawasan Antipolitik Uang Pada Masa Tenang dalam pemilihan Gubernur dan Wakil Gubernur, Bupati dan Wakil Bupati, Walikota dan Wakil Walikota Tahun 2020.

Masa tenang pada pelaksanaan pilkada di masa pandemi ini diharapakan agar masayarkat dapat membertimbangkan calon bupati dan wakil bupati kabupaten serang dengan matang dan tanpa adanya disrupsi, akan tetapi kenyataan yang terjadi tetap saja gaduh dibeberapa tempat dengan adanya politik uang dan kampanye terselubung, hal ini juga diperparah dengan sikap permisif dari masyarakat terhadap politik uang yang menyebabkan tindak pidana itu marak terjadi dan akan selalu terjadi.

Berdasarkan rekomendasi dari Bawaslu maka bawaslu Kabupaten Serang pada pelaksanaan pilkada serentak ini melakukan patroli pengawasan antipolitik uang bersama dengan jajaran Kepolisian dan Kejaksaan yang tergabung dalam Sentra Penegakan Hukum Terpadu (Sentra Gakkumdu), pelaksanaan patroli dilakukan selama tahapan masa tenang yaitu tiga hari menjelang hari pemungutan suara. Selain itu juga Bawaslu Kabupaten Serang melaksanakan penertiban alat peraga kamapanye (APK) menjelang hari pemungutan suara.

Berdasarkan keterangan dari Ketua Bawaslu Kabupaten Serang bahwa Patroli tersebut rutin dilakukan untuk mengantisipasi adanya praktik politik uang di masa tenang dan sekaligus menutup ruang-ruang agar setiap tim sukses tidak melakukan kecurangan terutama terlibat dalam politik uang di masa tenang. Dari pagi, siang, sore hingga malam Bawaslu Kabupaten Serang beserta Panwascam yang berada di setiap kecamatan akan menyelusuri semua sudut-sudut desa dan kelurahan untuk berpatroli mencegah adanya kecurangan tersebut.

Sebagaimana yang tercantum dalam surat edaran tersebut, pelaksanaan patroli pengawasan anti politik uang dapat dilakukan dengan cara kearifan lokal budaya masing-masing, maka dalam hal ini Bawaslu Kabupaten Serang 
melakukan dengan cara memberikan intruksi kepada jajaran Pengawas Kecamatan yang tersebar di 29 Kecamatan dan Pengawas Desa yang berjumlah 326 desa se Kabupaten Serang untuk ikut berbaur dengan masyarakat dalam setiap kegiatan seperti tahlilan, syukuran, istighosah atau kegiatan lain yang dianggap berpotensi disusupi oleh tim pemenangan masing-masing calon untuk memberikan uang atau barang lainnya sebagai upaya menggiring agar memilih pasangan calon tertentu. Dengan demikian kehadiran Pengawas dapat dilihat oleh masyarakat sehingga mampu menggagalkan upaya praktik politik uang.

\section{CONCLUSION}

Berdasarkan Analisa dan pembahasan diatas, penyelenggaraan pemilu memiliki wewenang antara lain mengawasi pelaksanaan tahapan-tahapan pemilu, menerima laporan-laporan dugaan pelanggaran pemilu, dan menindaklanjuti temuan atau laporan kepada instansi yang berwenang, terkait dengan strategi yang digunakan oleh Bawaslu Kabupaten Serang dalam menangani perihal politik uang di pilkada serentak strategi yang digunakan adalah dengan cara melakukan patroli politik uang dan selama tiga hari sesuai dengan surat edaran nomor 0822 K.Bawaslu/PM.00.00/12/2020 Tentang Pelaksanaan Kegiatan Patroli Pengawasan Antipolitik Uang Pada Masa Tenang dalam pemilihan Gubernur dan Wakil Gubernur, Bupati dan Wakil Bupati, Walikota dan Wakil Walikota Tahun 2020.

\section{Referencces}

Abhan, A. (2018). Peran Bawaslu Dalam Menjaga Kualitas Demokrasi Di Indonesia [PhD Thesis]. Fakultas Hukum UNISSULA.

Airlangga, S. P. (2019). Hakikat Penguasa Dalam Negara Hukum Demokratis. Cepalo, $3(1), 1-10$. 
Anshar, S. (2019). Konsep Negara Hukum dalam Perspektif Hukum Islam. Soumatera Law Review, 2(2), 235-245.

Asshiddiqie, J. (2011). Gagasan negara hukum Indonesia. Makalah Disampaikan Dalam Forum Dialog Perencanaan Pembangunan Hukum Nasional Yang Diselenggarakan Oleh Badan Pembinaan Hukum Nasional Kementerian Hukum Dan.

Aswandi, B., \& Roisah, K. (2019). Negara Hukum Dan Demokrasi Pancasila Dalam Kaitannya Dengan Hak Asasi Manusia (HAM). Jurnal Pembangunan Hukum Indonesia, 1(1), 128-145.

Azis, A. (2018). Constitutional Complaint dan Constitutional Question dalam Negara Hukum. Kencana.

Bachtiar, F. R. (2014). Pemilu Indonesia: Kiblat negara demokrasi dari berbagai refresentasi. Jurnal Politik Profetik, 2(1).

Gaffar, J. M. (2013). Demokrasi dan PEMILU di Indonesia.

Hofi, M. (2018). Prinsip Kedaulatan Rakyat Dalam Mewujudkan Pemilihan Kepada Daerah Yang Demokratis [PhD Thesis].

Jogiyanto Hartono, M. (2018). Metoda Pengumpulan dan Teknik Analisis Data. Penerbit Andi.

Jonaedi Efendi, S. H. I., Johnny Ibrahim, S. H., \& SE, M. (2018). Metode Penelitian Hukum: Normatif dan Empiris. Prenada Media.

Manar, D. G. (2018). Pilkada Langsung dan Rekonstruksi Demokrasi Indonesia. JIIP: Jurnal Ilmiah Ilmu Pemerintahan, 2(2), 12-17.

Manik-Fahriza, A.-E. N. G., Telaumbanua, H. B., Anggraini-Nur, I. B.-N. E., Salam, H. S.R., \& Marzuki, S. W. A.-Y.-W. (2019). PERIHAL PARA PENYELENGGARA PEMILU. 
Mu'as, A. (2015). Inkonsistensi Putusan MK atas penyelenggaraan pemilu serentak [PhD Thesis]. UNIVERSITAS AIRLANGGA.

Nabila Amrie, A. (2020). Peran Bawaslu Kabupaten Kebumen Mencegah Politik Uang Di Desa Anti Politik Uang Kabupaten Kebumen Perspektif Teori Al-Hisbah [PhD Thesis]. IAIN PURWOKERTO.

Nugrahani, F., \& Hum, M. (2014). Metode penelitian kualitatif. Solo: Cakra Books.

Nurlita, H. (2020). Penanganan Praktik Politik Uang Dalam Pemilu Tahun 2019 Di Kabupaten Banyumas Perspektif Maqasid Syari'ah [PhD Thesis]. IAIN Purwokerto.

Pratiwi, A. R. A. (2017). Pemilukada dalam Sistem Demokrasi (Telaah atas Siyasah Syar'iyah) [PhD Thesis]. Universitas Islam Negeri Alauddin Makassar.

Qamar, N., Syarif, M., Busthami, D. S., Hidjaz, M. K., Aswari, A., Djanggih, H., \& Rezah, F. S. (2017). Metode Penelitian Hukum (Legal Research Methods). CV. Social Politic Genius (SIGn).

Ridho, M. R. (2018). Kewenangan Badan Pengawas Pemilihan Umum Republik Indonesia (Bawaslu Ri) Dalam Menyelesaikan Sengketa Penyelenggaraan Pemilihan Umum (Pemilu)(Studi Kasus Sengketa Antara Partai Bulan Bintang Dengan Komisi Pemilihan Umum Republik Indonesia Pada Tahun 2018).

Siallagan, H. (2016). Penerapan Prinsip Negara Hukum di Indonesia. Sosiohumaniora, $18(2), 122-128$.

Surbakti, R., \& Fitrianto, H. (2015). Transformasi Bawaslu dan Partisipasi Masyarakat Dalam Pengawasan Pemilu.

Susilo, T., \& H Soehino, S. H. (2006). Pengawasan Pemilihan Kepala Daerah sebagai upaya mewujudkan asas langsung, umum, bebas, rahasia, jujur dan adil di 
Kabupaten Ogan Komering Ulu Timur [PhD Thesis]. [Yogyakarta]: Universitas Gadjah Mada.

Tamanaha, B. Z. (2012). The history and elements of the rule of law. Singapore Journal of Legal Studies, 232-247.

Wardhani, P. S. N. (2018). Partisipasi Politik Pemilih Pemula dalam Pemilihan Umum. JUPIIS: Jurnal Pendidikan Ilmu-Ilmu Sosial, 10(1), 57-62. 